\title{
Toronto Civic Workers Bargaining Without A Base: The Significance of 2012
}

\author{
CARLO FANELLI \\ Ryerson University ${ }^{1}$, Canada
}

\begin{abstract}
This article explores how the politics and economics of austerity has influenced collective bargaining between the CUPE Locals 79/416 and the city of Toronto. I explore the relationship between neoliberalism and workplace precarity, drawing attention to the importance of the municipal public sector to trade unionism and the political potential of urbanized Left-labour radicalism. Following this, I provide an overview of the repeated attempts by City Council to extract concessions from unionized workers with a focus on the concession-filled 2012 round of bargaining and its relationship to earlier rounds. In what follows I discuss the implications of austerity bargaining for Locals 79 and 416 members, drawing attention to the repercussions this may have for other public sector workers. To conclude, I propose an alternative political strategy for municipal public sector unions, stressing the importance of a radicalized labour approach. It is my contention that this requires the development of both alternative policies and an alternative politics rooted in demands for workplace democracy and social justice.
\end{abstract}

Public sector austerity has been a main staple of policymaking since the onset of the Great Recession. While cultivated in earlier forms of austerity, recent initiatives across scales of public administration indicate a significant opening-up of the public sector in order to create new spaces of accumulation, extract wage and benefit concessions from unionized workers, and erode and dismantle what remains of public sector services and assets. This article examines how the politics of austerity has influenced Canadian Union of Public Employees (CUPE) Locals 79 and 416 in the city of Toronto. I begin with an overview of the relationship between neoliberalism and workplace precarity, with a focus on the importance of the municipal public sector to trade unionism and the political potential of urbanized Left-labour radicalism. Next, situated in historical perspective, I provide an overview of the repeated 
attempts by City Council to extract concessions from unionized workers with a focus on the concession-filled 2012 round of bargaining and its relationship to previous rounds. From there, I discuss the future implications of austerity bargaining for Locals 79 and 416 members, drawing attention to the repercussions this may have for other public sector workers.

To conclude, I highlight an alternative political strategy for municipal public sector unions, stressing the importance of a radicalized labour approach. It is my contention that this requires the development of both alternative policies and an alternative politics rooted in demands for workplace democracy and social justice. My research is informed by my experiences as a part-time worker with the City of Toronto for over a decade, a participant in three strikes since 2000 and as a picket captain with Local 79 through the 2009 strike. Grounded in a critical political economy approach, my analysis is informed by engaged participant observation and a first-person scholarly account of how new pressures for concessions are affecting municipal workers in Toronto. This study, like earlier research (Fanelli, 2014a), grounds my intellectual work by supplementing textual evidence, union documents and media reports with an insider's assessment of how austerity is affecting services provisioning, the working environment and collective bargaining. One of the advantages of being a participant observer and trade unionist is that I was able to gain access to a group of workers who may otherwise object to being studied by non-union members. As such, participants generally behaved as they ordinarily would, which meant that my research was open to new insights and evolving areas of inquiry. In utilizing such a method of research, I was able to collect and interpret data which might be unavailable or missed using other methods. I also draw on existing scholarly works, Statistics Canada data, newspapers as well as formal and informal interviews in order to supplement the qualitative data I have collected.

\section{Neoliberalism, Precarious Work and Austerity}

In both practice and political ideology, neoliberalism is many-sided including a broad set of macroeconomic policies, a worldview and an approach to public policy. Neoliberalism's intellectual roots, both ideational and ideological, can be found in the classical liberalism and the economic writing of Von Mises, Hayek and Friedman (Peck, 2010; Stedman Jones, 2012). Although an offspring of the Great Depression, the Keynesian crisis of the 1970s reignited latent class antagonisms culminating in the three-decades-long struggle for neoliberal hegemony. Neoliberalism's most vocal expositors took a longestablished core of liberal values and refashioned them in new form. In this sense, the intellectual inspiration and policy developments of neoliberalism have been multidimensional, variegated and heterogeneous across time and space. Neoliberalism can be understood as the latest set of socio-spatial and institutional configurations in the ongoing development of a capitalism composed of conflicting tendencies toward destruction and creation (Brenner 
\& Theodore, 2002a).

As a political project, neoliberalism has been characterized by a capitalist class and state offensive in which the aim has been to rescind the collective gains made by labour in the quarter-century proceeding WWII, while at the same time extending new forms of commodification (Brenner \& Theodore, 2002a; Peck, 2010; Peck \& Tickell, 2002). In this regard, neoliberalism is a politically guided, yet frequently contested, process seeking to alter the balance of class forces in favour of capital at the expense of labour. This restructuring has had especially harmful consequences for the delivery of public services, the workers delivering those services and the users of those services. At the root of this restructuring is a socio-spatial, historical and political process seeking to extend and deepen the relationship between the state and the market. Understood this way, neoliberalism is not a juxtaposition of (less) state against (more) market, but rather about a particular kind of state suited to the logic of capital in a specific historical phase of capitalist development. This has included reducing public services and assets in order to open up the state sector to new profit-making opportunities; lowering wages, benefits and working conditions for a more flexible and market-dependent workforce; and deploying the coercive apparatuses of the state to enforce these market mechanisms. The politics of austerity and policy practices since the Great Recession, then, should be understood as a class strategy that takes further steps toward the 'total privatization' of the public sector (Albo \& Fanelli, 2014).

In an effort to reduce service costs, many public sector employers, like their private sector counterparts, have adopted a neoliberal approach to employment which is achieved through the temporary and discretional use of layoffs, labour intensification, the denial of benefits and retrenchment of wages. This has included the curtailment of free collective bargaining rights, management strategies that promote multi-skilling, continuous re-training, performance-based pay, tightly controlled managerial practices and enhanced workplace supervision (Camfield, 2011; Evans, 2013; Panitch \& Swartz, 2003). What's more, feminist and anti-racist political economists have identified key dimensions of neoliberal policies which often go unaccounted for in analyses that neglect racial- and gender-based oppressions. For instance, in the context of persisting gendered and racialized divisions of labour, the reduction and privatization of social services have increased both the demands on women's responsibilities in the home and exacerbated lowwage occupational job segregation (Braedley \& Luxton, 2010; Jenson \& Sineau, 2001).

Furthermore, from the reduction of child and elder care services to ongoing workplace-based segregation, the broad policy matrixes of neoliberalism have further reinforced Canada's gender- and colour-coded labour market (Block \& Galabuzi, 2011). This is especially pertinent to women and racialized groups in the public sphere where they have made the most gains and labour market segmentation is less pronounced in comparison with similar private sector work (Baines, 2013; Briskin, 2013; Pupo \& Noack, 2010; Warskett, 
2013). As neoliberal policies are ingrained across the public sector, gender and racialized labour market inequalities are further sharpened as weakened labour market and income security protections worsen historical patterns of marginalization. This is reflected, for example, in women's and racialized groups' over-representation across low-income occupations as well as in higher rates of poverty (Block and Galabuzi, 2011; Lewchuk, Clarke, \& De Wolff, 2011; Braedley \& Luxton, 2010). Thus, as ethno-racial and genderbased inequalities, rooted in fundamentally antagonistic class relations, are further intensified through the marketization of public services, the burden increasingly falls on historically racialized groups, women and (im)migrants, to occupy the most precarious labour market positions.

In the alleged absence of market failure, the principle of individual failure has come to dominate public policy debates as collective social policymaking increasingly fades from view. With the dissolution of the Keynesian maleincome-earner model, the neoliberal employment relationship is one characterized by increasingly insecure labour market arrangements, low pay, the absence of benefits or entitlements and growing work-life imbalances (Vosko, 2006). ${ }^{2}$ As a means of "rationalizing" the elimination of public services and deteriorating working conditions, proponents of neoliberalism have promoted tax cuts as a cure for nearly all of society's social ills. To borrow from Marx, tax cuts have become the new opiate of the masses. Such changes in the nature and content of public policy have had significant implications for labour market conditions as the generally inferior working conditions and wages of the private sector have become the new benchmark which, in the process, has provided the rationale for attacking public sector workers' compensation.

The ongoing transformation of the public sector via policy prescriptions expounding the virtues of neoliberalism have perhaps been most apparent with the growth of New Public Management (NPM) theories which have sought to "modernize" the public sector through "efficiency"-generating principles based on private sector management models. By increasing market exposure, proponents of NPM advocate a transition from public "administration" to public "management" via the privatization of public goods and services, a greater reliance on outsourcing, contracting-out and user-pay provisions. Competition between public agencies and private firms is alleged to increase cost-effectiveness, while the use of short-term and contract labour, including performance-related pay and bonuses, is envisaged as constructing a "lean" state (Sears, 1999). NPM theories, like the overarching neoliberal framework in which they are embedded, seek to enhance capital accumulation by limiting trade unions' rights and freedoms, privatizing public services and employment, and establishing the generally inferior private sector labour practices in the public sector. This restructuring has had particularly deleterious effects on racialized groups and women at the municipal scale as both the quality of work and the mental well-being of workers have declined (McDonough, Worts, Fox, \& Dmitrienk, 2008; Worts, Fox, \& McDonough, 2007; Baines, 2004). 
In Canada there are some important differences between how neoliberalism has affected private and public sector work. Whereas casualization in the private sector has been mainly in long-term part-time work, it has taken place primarily though temporary full-time work in the public sector. Thus, in the public sector, short-term full-time work has eclipsed permanent parttime employment as the main form of casualized labour. Given significant structural forms of discrimination, such as those historically linked to the female gender wage-gap and racialized exclusions, transformations in the quality and form of public sector work and working conditions remain important given that nearly one in five Canadians, sixty-one percent of which are women, work in the public sector (Stinson, 2010).

The public sector remains a crucial stronghold of Canadian trade unionism. ${ }^{3}$ It is this very strength and potential that help explain why public sector workers and their unions have come under such political and economic consternation from across the political spectrum. Furthermore, given public sector workers' concentration in urban centres and their strategic location as the providers of a broad range of services, they are in a unique position to build deeply integrated labour-community alliances fighting for the pursuit of social justice and expanded public services (Brenner \& Theodore, 2002b, 2005; Harvey, 2009; Turner \& Cornfield, 2007). Workers employed by municipal governments are in a distinctive position to build popular political support, since municipal services are typically provided and consumed in a shared geographic region. In many cases, these workers provide essential services to others in the city, but are often also the users of those services. Thus, there is a greater potential to build solidarity in the struggle to defend and transform the provision and governance of public services because they appeal more directly to people's everyday lives.

It is in the context of an increasingly urbanized planet that cities and wider metropolitan regions have become pivotal sites for, on the one hand, the elaboration of neoliberal projects and, on the other hand, central sites of contestation. Yet, cities are much more than merely ideological and institutional experiments of neoliberalism. They are also important sites for mass rebellion and collective action, wherein a range of progressive Left organizing, labour militancy and alternative visions for urban life may be developed, challenging the narrow policy parameters of neoliberalism as well as the structural constraints of capitalism (Brenner \& Theodore, 2012b; Harvey 2013).

As will be shown in the case study of the 2012 round of collective bargaining between municipal workers and the City of Toronto, the local state sought to deepen and extend market imperatives by cheapening labour and making paid employment more precarious. Eroding trade union rights and freedoms has been a recurring feature of neoliberalism (Fanelli, 2013; Panitch \& Swartz, 2003; Ross \& Savage, 2013). In this regard, many local governments are implementing broad programs of "austerity urbanism" (Peck, 2012; 2013), which in some cases is driving a fiscal crisis at the urban scale. Although municipal fiscal crises have been a recurring problem for some three decades 
as fiscal capacities could not keep up with increased pressures for service demands and urbanization, this process of neoliberal urbanism has escalated over the past decade as tax-shifting for competitiveness and reductions to social services, as well as the 2008-10 economic crisis, have combined to intensify neoliberal urbanism (Boudreau, Keil, \& Young, 2009; Fanelli, 2014a, 2014b; Hackworth, 2007).

\section{Continuity and Confrontation: Collective Bargaining at City Hall}

The Canadian Constitution has never regarded municipal corporations, as they are formally called, as sovereign political entities. ${ }^{4}$ Rather, from the very beginning they were subject to the rights and powers conferred on them by their respective provinces. Across Canada, municipal labour relations have in the main fallen under general or private-sector labour relations statutes (Fudge and Tucker, 2001). Since the 1980s, neoliberal policy experiments have been a chronic feature of Canadian pubic administration (McBride, 2001). Under this truncated and uneven process of marketization, many federal, provincial and municipal governments have resorted to reducing public services, eroding investments in public assets and infrastructure as well as demanding concessions from workers delivering key services. Canadian municipalities in general and Toronto in particular have had a long history of dealing with the structural constraints of urban neoliberalism (Albo, 2009; Boudreau et al., 2009; Fanelli, 2014a, 2014b; Fanelli \& Paulson, 2012; Keil, 1998; 2002; Keil \& Kipfer, 2002). This has affected municipal workers most acutely. While this is not the place for an exhaustive overview of CUPE Local 79's history of bargaining with the City of Toronto, some brief discussion is nevertheless necessary in order to trace the continuity in concessions and confrontations between earlier rounds and the 2012 rounds of bargaining. ${ }^{5}$

The 1980s and 1990s was a period of significant budgetary austerity for federal and provincial governments which looked to shed "liabilities" by transferring administrative and financial responsibility for public services and programs onto other tiers of government (McBride, 2001). Over the 1980 s and 1990s, the municipal political economy increasingly moved away from manufacturing goods towards banking, finance, insurance and real estate services (Boudreau, 2000; Boudreau et al., 2009; Caulfield, 1994; Friskin, 1993; Lemon, 1985). Over the Keynesian period, Toronto became the strategic nodal point connecting Canada to the global economy. The period of neoliberalism since the 1990s has sought to deepen and extend these connections, remaking Toronto in the form of an ultra-competitive "global city" (Kipfer \& Keil, 2002; Lemon, 1985; Todd, 1998). This process reached its apogee in 1998 when six surrounding boroughs were merged, creating the new single-tier "megacity"- one of the world's few major cities created by and for neoliberal purposes (Carson \& Siemiatycki, 2014). In this sense, Toronto has long been a laboratory of neoliberal experimentation in the remaking of the local state. This reengineering of the local state was 
not, however, accompanied by the transference of administrative and fiscal powers. As a result, this intensified inter- and intra-city competition between and within Toronto and its surrounding municipalities.

In an effort to deal with post-amalgamation fiscal challenges, the City of Toronto has recurrently tried to extract concessions from its unionized workforce. ${ }^{6}$ These initiatives have revolved around extracting wage and benefit (primarily job security) concessions from workers and attempts to outsource and privatize public services and assets for profit-making opportunities. In 2000 and later in 2002, Local 79 and 416 twice struck against the city's demands for concessions. In the latter case, the Local's right to strike was suspended as the provincial Conservative government, with the backing of a majority conservative City Council, legislated them back to work. As part of this administrative reorganization of state capacities, the aim was not to bypass or supersede the state, but to create a different kind of state as part of a broader strategy of enhancing competitiveness within the city and vis-à-vis other jurisdictions.

Local 79 is the largest municipal union in Canada. Thus, the extent to which neoliberal reforms are implemented in the Toronto municipal sector often has implications for other jurisdictions. Through the period of neoliberalism, the city has experienced significant growth of producer services and media capitals, as well as a whole range of low-wage service and hospitality industries, especially professional services tied to housing-related demand for credit, renovations and legal services. As the centre of financialization in Canada, Toronto, like other "global cities," has become highly dependent upon the internationalization of capital. As such, the city has undergone a significant restructuring of both municipal government and services, as well as changes in the City's relationship with its employees and the broader economy. Far from a casualty of a globalized economy, this restructuring has been a politically guided process - non-linear and frequently challengedseeking to deepen and extend the relationship between the state and market. Said differently, the state has in some instances led and in other instances created the conditions for capital to lead in remaking the conditions of work and labour, further integrating neoliberal imperatives. In line with federal and provincial attacks against free collective bargaining, the local state has undertaken an aggressive program of urban austerity.

In the case of the 2009 round of bargaining, four issues were central: defending attacks against the controversial Sick Leave Benefit Program (SLBP) which allowed for the banking of sick days; staving off attempts to erode job security provisions, seniority rights, transfer and promotional opportunities; challenging a freeze on cost-of-living increases to wages as well as the implementation of two-tiered wages; and curtailing attempts by management to contract-out employment and increase control over the labour process through enhanced disciplinary and surveillance measures. Throughout bargaining, the economic uncertainty stemming from the Great Recession served as a political and economic pretext justifying and intensifying the neoliberal reconfiguration of the city. Despite a "progressive 
coalition" at City Hall made up of New Democrats, Liberals and a few independents, Council set forth attacking labour in order to meet its fiscal challenges - challenges generated by capitalism in economic crisis and the policies of neoliberalism. In short, after 39 days on strike, an agreement was reached between Locals 79/416 and the City of Toronto.

Economically, both Locals managed to stave off major concessionary demands to freeze wages, institute a multi-tiered wage system and limit seniority-based promotion. The banking of sick days and cash payouts was replaced with a short-term disability plan that extends paid-leave until a third occurrence after which pay is reduced. Both Locals were successful in gaining 2 percent raises over 3 years. Local 79 part-timers, however, did not see any extension of benefits nor do they have now any form of a sick plan. The other concessions were taken off the table. As will be shown shortly, however, the economic gains of the strike were a hollow achievement as the political implications of the strike far outweighed the minor and temporary economic benefits of the agreement. The strike was a political failure when it came to mobilizing sustained action and education, garnering public support as well as linking the defense of unionized workplaces with fighting for workers in non-unionized jobs and the un(der)employed.

What's more, the outcome of the strike exposed Locals 79 and 416 as both strategically and politically unprepared in important ways. First, the executive committee bargained in almost complete isolation from the rest of the membership, failing to build active solidarity from the bottom up. Second, the union did not book members off as full-time organizers until right before the strike was set to start. This resulted in poor organization and cooperation amongst members as well as with other labour and community groups, resulting in a significant lack of solidarity amongst unionized and non-unionized workers. Third, financial and personnel resources were allocated in ineffective and inequitable ways across the city's regional strike offices. Fourth, beyond administrative assistance and very minor input in decision-making processes, CUPE National played a very limited role in the broader coordination of bargaining despite the fact that this could have established the pattern of bargaining across CUPE's other 250 municipal Locals. This raises a set of issues which, although outside the purview of this article, are related to CUPE National's notoriously fragmented approach to bargaining and the enduring tensions related to national leadership and local autonomy. These questions are themselves enmeshed within broader debates about the structure of the union, its priorities, vision, and strategic outlook (Ross, 2005).

As a result of these combined pressures, many members were resentful toward the executive and the politics of the strike as public condemnation mounted and workers were marginalized. This was reflected in low morale on the picket lines as well as in a lack of awareness of the key issues involved in negotiations. Furthermore, despite over one month on strike, the agreement did not make work any less precarious, particularly for part-timers, women and racialized groups that make up the bulwark of unionized members. With 
some political imagination the strike could have been strategically situated in relation to a number of connected issues such as past experiences of public services privatization, taxation and revenue generation as well as poverty and income inequality. Likewise, decades of downloading could have been related to the broader attack against labour across traversing scales of public administration and in the private sector. While the strike was not an absolute failure, illusions about the strike being a victory impeded rather than obliged serious discussion about the shortcomings of the 2009 round of bargaining and its implications for future rounds.

\section{Bargaining: Paved With Concessions}

The 2012 round of collective bargaining served as a litmus test for both the City of Toronto and Locals 79 and 416 in a battle of opposing class interests. As noted earlier, austerity's impacts are not class neutral, but rather a capitalist class strategy that is simultaneously racialized and gendered. Hypothetically, if the City were able to extract a host of concessions from the unions, this would signal an open attack across municipalities and the broader public sector. On the other hand, if Locals 79 and 416 not only managed to hold off concessionary demands, but actually extended those benefits to those most precariously employed and tied those gains to the community groups they served, it might have sparked a fight-back in the public sector serving also as an example for other private sector unions. Unfortunately, the outcome of the 2012 round of collective bargaining tended toward the former scenario, likely serving as a template for other municipalities across Canada.

Under the leadership of authoritarian populist Mayor Rob Ford (Kipfer \& Saberi, 2014), it was clear from the beginning that the City's negotiating team would be taking a hard-line position during negotiations. ${ }^{7}$ Having made significant inroads to concessions during the 2009 round of bargaining, the City used the unpopularity of the previous strike as an opportunity to further extend their mandate of austerity and attacks against workers. The Employee and Labour Relations Committee (ELRC), a subcommittee of mostly conservative councillors hand picked by the Mayor, was responsible for negotiating with the unions' various bargaining committees. The ELRC did not need the approval of council to lock out workers or unilaterally alter the terms of the contract. Locals 79 and 416's collective agreements expired January 1, 2012. By October 2011 the City had already served notice to Local 416 to begin bargaining. As will be argued, this formed part of the City's broader Machiavellian orchestration to thoroughly defeat what remained of trade union militancy in Locals 79 and 416.

While talks had started months earlier, by mid-December 2011 both the City and Local 416 were accusing each other of bargaining in the media. To what extent this was grandstanding is unclear, but by this point the City had already requested a conciliator as mandated by law. Just three days into the new year, the City of Toronto informed the Ministry of Labour that bargaining 
had reached an impasse. Two issues were crucial at this juncture. First, upon receipt of the City's request, the Ministry of Labour could issue a "no board" report, which meant that after a period of seventeen days the City could lock out workers, unilaterally impose conditions or go on strike. Second, the City used the time in between the issuance of a "no board" and a deadline as an opportunity to publicly bargain and intimidate workers into accepting the terms of a new agreement. Rather than threatening a lockout, the ELRC argued that unless the terms of a new agreement were accepted, they would be unilaterally imposed. In order to meet the challenges of a "cash-strapped city," argued councillors and media pundits, workers would need to concede wages and benefits and, most of all, job security.

While negotiations faltered, on January 13, 2012 Local 416 held a press conference to try to sway public support. The union's announcement was straightforward. In return for rolling-over the existing contract, the union would forego wage increases for the duration of the contract. A moratorium on wage increases would translate into approximately $\$ 10$ million in yearly savings. Local 416 also made the case that public sector workers should not be made to pay for an economic crisis not of their making. But the City immediately rejected what representatives of the ELRC deemed a public relations ploy, stressing that what was central in this round of bargaining was employer "flexibility" not wage concerns. In this regard, the recasting of working people and job security as outmoded entitlements has been one of the great successes of neoliberalism.

Despite Local 416's very public play, the City continued to push for the complete removal of a no-contracting-out clause that required workers whose jobs were eliminated or technologically displaced to be redeployed to another position. Additionally, the City was seeking reductions to health and dental benefits as well as the termination of a clause that required the City to collect dues for the union. For accepting these so-called productivity-enhancing amendments, the City would give workers a lump sum payment of 1.5 percent. The City later sweetened the pot by offering job security to those with at least 25 years of seniority, while the union moved from a position of no-concessions bargaining to job security for those with five years of experience (a divisive strategy on the part of the City which created a row between newer and older members). While the City continued to bargain with Local 416, Local 79 was focused on replacing its outgoing president and executive council, playing a very minor role as Local 416 continued to bargain. On January 18, 2012 a "no board" report had been issued which meant that a February 5th deadline had been set. The City continued to publicly stress that unless the union gave up "jobs for life," an agreement would be imposed. This was framed in terms of increasing innovation, efficiency, flexibility and saving "taxpayers" money, as well as in terms of rebalancing "managerial rights" (Deputy Mayor Doug Holyday in Dale and Boyle, 2012). Members of the ELRC argued that public sector labour contracts must fall in line with the private sector. The City and union bargained past the deadline, reaching an agreement on February 13th.

Four terms of the agreement are central. First, the new agreement includes 
language that allows the City to unilaterally make any changes to shift schedules so long as employees are served notice. Job performance criteria are now used to determine shifts and scheduling. This was a concession the City tried to force in 2002, 2005 and 2009, as the previous contract required that the worker and union agree to any shift/scheduling changes. Second, the new contract removes a letter of agreement that provided protection to all permanent employees regarding contracting-out or technological displacement. Under the new agreement, the threshold of protection was reduced from covering all workers to only those with at least 15 years of seniority (a decrease of coverage from 100 to about 68 percent of employees). This was also tried in previous rounds of bargaining. Third, the City reduced the amount of coverage for health and dental benefits which, according to the terms of the new agreement, is expected to save the City some $\$ 20$-35 million, and also eliminated the expected post-retirement liabilities of \$54 million. Fourth, in return for giving up a significant portion of their job security, workers received a one-time bonus of 1.5 percent, 0 percent in 2012 , 0.5 percent in 2013, 1.75 percent in 2014 and 2.25 in 2015. A remaining issue left over on the table is that related to reducing workplace absenteeism. Both the union and the City have agreed to study the matter further in what will likely be a major point of contention in the next round of bargaining.

With Local 416 having set the bar, the agreement was essentially rolled over to Local 79, which put it up for a vote without recommendation. Of Local 79's four bargaining units, two units (Full-time and Part-Time Unit B) voted to accept the deal as is, but recreational part-time workers voted the deal down. The City and Local 79 went back to bargaining and were able to obtain some minor changes that increased the amount of hours an employee is allowed to work in a particular position as well as included the provision of paid time for mandatory recertification. Part of the recreational part-time workers' antipathy toward the deal stemmed from a recent arbitrator's decision that harmonized downwards pay, hours and recognition of expertise still lingering from the amalgamation of city workers in 1998. A fourth unit representing part-time employees of Long-term Care Homes and Services facilities also rejected some aspects of the new agreement due to a reduction of work hours and ongoing scheduling conflicts, but that dispute was sent to binding arbitration as these workers are deemed "essential." As the experiences of labour history generally and Local 79 in particular have shown, small concessions beget larger concessions and unless workers are prepared to take job action, they will be hard pressed to resist demands for future concessions. ${ }^{8}$ Unfortunately, while the City of Toronto may have drawn important lessons from the experiences of 2009, Locals 79 and 416 seem to be undergoing a slow-motion death by a thousand cuts. In other words, Locals 79 and 416 continue to travel down a road paved with concessions without a cohesive strategy or political pushback to match the state's and capital's offensives. 


\section{Lessons (Not) Learned: Labour's Last Gasp or Comeback?}

Since the 1980s, the centre of gravity in the Canadian labour movement has gradually shifted from one centred in the predominantly "blue-collar" private sector to one increasingly centred in the "white-collar" public sector and female-led. With some 70 percent of the public sector still unionized, compared to about 16 percent in the private sector, the attacks on public sector unionism threatens to consolidate the defeat of labour (Ross \& Savage, 2013). In light of the string of concessions for Locals 79 and 416, it was clear that the City of Toronto had drawn important lessons from the experiences of 2009. Equally important, it was evident the City, unlike the union, was thinking in broader class terms. With more than 250 CUPE Locals bargaining across Canada, municipalities and capital were watching closely as the experiences of Toronto served as a template for other jurisdictions preparing to take on their public sector workers. "Municipalities will pay attention to what's happening here," argued Deputy Mayor Doug Holyday. "[This round of bargaining is] the defining experience in our city's recent history," he added. And, "It hasn't been done [in the public sector]," added councillor Denzil Minnan-Wong, "No one else had the balls." (Ridler, 2012; Grant, 2012). In place of labour radicalism, then, it has been state militancy that has seized the moment and adapted to the conditions of recession and austerity. As one executive member of Local 79's bargaining committee put it, unions have not adapted to the conditions of the 21 st century which require a new radicalized approach. "Now I know what it feels like to be an autoworker." (Personal Communication 1, 2013). Indeed, in an ambitious strategy more than a year in the making the City undertook a number of important initiatives that require further thought.

First, in order to avoid summer bargaining (and potentially a summer strike with garbage once again lining the streets), the City served notice to begin bargaining to Local 416 (which includes waste disposal workers) months in advance of the contract expiring. As part of the strategy, the aim was to divide and separate from one another different Locals, especially the largest, Local 79, whose contracts expired around the same time. ${ }^{9}$ Second, the City put together an aggressive negotiating team stacked with management firm lawyers with vast amounts of experience extracting concessions from unionized workers. This assisted the City in successfully establishing the tone of bargaining early as they engaged in a public relations campaign to delegitimate and marginalize Locals 79 and 416 (Grant, 2012). Third, rather than lock out workers, the City of Toronto threatened to unilaterally impose contracts and alter the terms of employment. This was an unprecedented move by a Canadian municipality, although it shares precedent with moves first undertaken in the U.S. industrial sector and later deployed by various tiers of government (Fletcher \& Gapasin, 2008; Moody, 1997). Its legality, however, has not been established in the Canadian public sector. ${ }^{10}$

Fourth, in the event of a strike the City was prepared to implement a sixmonth contingency plan, which they did not have back in 2009. The City 
was prepared to install hundreds of cameras at different picket sites and implement a waste management plan that would establish trash drop-off sites at yards and arena parking lots rather than city parks. Collectively, these strategies worked brilliantly to stifle, undermine and get the better of Locals 79 and 416. It should also, once and for all, expose the limitations of CUPE's, the Locals' and the Toronto and York Region Labour Council's excessive emphasis on lobbying individual councillors. Councillors' first priority is to get re-elected and, as the 2009 round of bargaining with a labour-friendly "social-democratic" Mayor and "progressive council" showed, individual councillor support often hinges on broader public opinion (Fanelli, 2014a; Kipfer \& Saberi, 2014; Carson \& Siemiatycki, 2014). In light of recurring concessions, the question then is: what are CUPE as a union and specifically Locals 79 and 416 prepared to do? How might unions rebuild their capacities while renewing an emphasis on working class politics?

With the backing of ruling class circles, Mayor Ford and conservative councillors continue to push a program of austerity infused with a deeply racialized, gendered and classed form of authoritarian populism (Kipfer \& Saberi, 2014). Considering the concerted attacks against labour, should unions wish to regain their once-prominent role in the pursuit of social justice and workplace democracy, they will need to take the risks of organizing working class communities and fighting back while they still have some capacity to do so or risk continuing the decades-long labour impasse and union decline. In my view, this requires a radicalized perspective that seeks to develop both alternative policies and an alternative politics rooted in the working class. The failure to do so may consolidate an impending class defeat. In what follows, I outline some thoughts on strategy that might aid in developing a radicalized labour movement and Left politics.

It is a well known truism that exclusion from the benefits of unionization often builds resentment which has been made more intense in a neoliberalized landscape where the social welfare state has been dismantled. A genuine engagement requires taking stock of this dismantling and how badly and disproportionately it is affecting poor people and marginalized communities. Rebuilding unions and renewing working class politics must engage directly with that resentment if it is to counter the drumbeats of austerity and retrenchment (Fanelli, 2014c). Future contract negotiations will not only be the test of the Ford agenda and whether conservatives can consolidate their hold over Council, but will reveal whether the Toronto and Canadian labour movement as a whole is up to the task of fighting back. In the absence of such a fight back, Mayor Ford and Council, with the support of Toronto's and Canada's ruling classes, will continue to be forceful with respect to layoffs, service cuts, asset sell-offs and attacks against labour. This setting requires some exploratory thinking on a progressive labour strategy, in particular for CUPE Locals 79 and 416, given the harsh fact that the economic crisis has so far strengthened reactionary forces and efforts to reconstruct neoliberal policy frameworks. Of course, such rethinking also has broader implications for unions and community activists as a whole. 
First, previous strikes by Local 79 and 416 have made it painfully clear that the Locals cannot go into bargaining alone. Even with the limited support of CUPE National, community groups, social justice activists and other progressive unions, the mobilizational capacities, resources, organization, community and political support were not sufficient. As one activist member of Local 79 put it, "The new leadership is doing a much better job with outreach and advocacy, but it is not enough. What's worse, if federal legislation like allowing secret ballots during strikes, banning the use of dues for so-called political purposes, requiring increased financial disclosure by unions, removal of the RAND formula, and right-to-work legislation passes, CUPE could lose up to 20 percent of its membership. In Ontario we're in serious trouble... as if it wasn't already bad enough! We're talking about the survival of collective bargaining here..." (Personal Communication 2, 2013). Transforming our unions internally and solidifying their relationships to others affected by the concerted push for austerity means not only building on the successes of earlier struggles (Carson \& Siemiatycki, 2014) but also confronting the shortcomings of previous strategies. Calls for solidarity without substance are mere posturing, just as militancy for militancy's sake is reactionary and might well pave the way for future defeats. The challenge confronting Locals $79 / 416$ and other unionized workers is to take the necessary steps in order to avoid sounding militant but then reproducing the status quo.

In other words, issues around rank-and-file mobilization, sustaining engagement and deepening coalitions beyond defensive struggles are central to (re)building workers' political and organizational capacities. While strikes can be explosions of class consciousness, the working class solidarity they generate rarely gathers momentum beyond the immediate event (Mann, 1973). Hence, while strikes may lead workers to question the unequal relationship between employers and employees, those concerns rarely translate into a coherent awareness of class differences and class struggles, let alone critical assessments of deficiencies in the political structure or capitalist system. Militancy alone rarely accomplishes much beyond spontaneous bursts of discontent and may well be constrained by workplace particularism. Indeed, bursts of "militant particularism" might fizzle just as quickly as they erupted (Williams, 1989; Mann, 1973; Harvery, 1996). While strikes are certainly important and can go a long way toward galvanizing broader community support in defense of decent jobs, the challenge is to connect these seemingly particular or localized concerns to a broader political project that makes clear the relationship between individual subjectivities and structural forms of oppression. As elucidated by Harvey, the paradox of militant particularism is that it often develops amongst one group of workers at the expense of workers elsewhere, stifling a more universal working class, socialist consciousness and movement across space or particular locales. Moderating expectations and seeking to arrive at an equal partnership with so-called responsible politicians and businesses in the hope that labour will gain a seat at the table have been proven time and again over the course of history to be fool's gold. Rather, as recently argued by Sam Gindin (2013, p. 244), 'the radical is 
increasingly the only thing that is practical...'

As part of dealing with past failures, CUPE Locals 79 and 416 must come to the bitter realization that the existing way of doing things simply is not working anymore. Although a product of historical differentiation among blue-collar and white-collar workers, CUPE Locals 79 and 416 will need to seriously consider merging and doing away with what are otherwise arbitrary and eroding distinctions between its workers. Their independent and collective futures depend on it. Other unions have partly recognized the impasse and taken similar steps (Stanford, 2013). Many of the positions of CUPE Locals 79/416's workers often intersect, are co-dependent and take place in the same location. Additionally, the terms of one Local's contract often set the terms of pattern bargaining for other Locals, so they have a vested interest in one another just as they do with other unionized City workers (e.g. library workers, police ${ }^{11}$, fire, Toronto Hydro, etc). Confronting austerity means rethinking sectional divisions among unionized workers.

Second, as a public strategy, the issues of bargaining and keeping services and assets public should be at the centre of the unions' demands. This message might help to reveal linkages between the users and producers of services as well as the shortcomings of past examples of privatization and contracting-out (Armstrong et al., 2001; Loxley, 2010). Advocating for public services would need to demonstrate their superior quality while acknowledging existing shortcomings and putting forward alternative solutions for making them better that enhance democratic participation and are not market-oriented. This could be framed as not wanting to hand ownership and control over to the "1 percent" and questions of democratic decision-making. Local 79's "Taking Care of Toronto" radio, internet, billboards and television ads are a good start, as is Local 416's campaign for public services, but the limitations of media public relations campaigns need to be made clear. There are no substitutes for face-to-face interactions and civic engagement, and these need to happen within the workplace and extend into the city's neighbourhoods. Rebuilding trade union capacities and working class politics requires integrating as well as going beyond social media campaigns and engaging in the concrete struggles of labour and community groups, including protests, sit-ins, workplace and public space takeovers, minimum-wage and "good jobs" campaigns. In an era of unprecedented income inequality and labour degradation, keeping the public service could be tied to the growth of precarious work, youth unemployment, higher minimum wage campaigns and general social insecurity tapping into a wellspring of discontent.

Third, past experiences have shown garbage collection to be a lightning rod for public and media disdain. Although representative of a minority of workers on strike, it is without question the most visible and conflict-ridden source of frustration. Preventing Torontonians from disposing of their waste is also the most politically volatile and, in my view, foolish of tactics. In addition to exposing what happened in other similar cases of contracting-out garbage collection - underbidding and then falling services and escalating costs (TEA, 2011) - the Locals needs to tie the issue of waste management 
to climate change, public health and sanitation. But preventing communities which might otherwise be on the side of workers by prohibiting them from getting rid of their waste is not only a poor strategic move but reinforces the portrayal of unionized workers by the media, management and others as indifferent to the needs of the communities they serve. Furthermore, preventing community members from disposing of their waste will do little to disrupt the functioning of the city's day-to-day activities. As was obvious in 2009, despite 39 days on strike, the City could have gone on for months more filling waste yards.

Alongside the public's obvious frustration, a majority of workers do not work in waste disposal, which meant, for example, that recreational staff, EMS workers, water, parks and road maintenance workers, animal services, child and elder care workers, public health nurses and social workers with little to no experience with waste disposal, were tasked with shutting down these facilities and devoting their energies in arguably futile ways. Perhaps there is a way of using these highly skilled workers' knowledge and abilities in ways that demonstrate their important contributions to city services. In other words, is there a way of utilizing striking workers so that a broader connection can be made between services and communities, privatization and public goods? In 2009, there were certainly other picket lines throughout the city that demonstrated this, such as those at social services centres and councillors' offices, which suggests that only new forms of strike action could reorient the public's perception away from the stigma of a "garbage strike" and toward a strike about keeping services public. ${ }^{12}$

Fourth, Locals 79 and 416 continue to struggle with moving beyond the limitations of past strikes and rethinking the way union organizing needs to adjust to the new climate of austerity bargaining. Past experiences suggest that Local 79 has had great difficulty creating a larger rank-and-file bargaining team that does not rely exclusively on executive-led mandates. While part of this is simply a matter of logistics, it is also a matter of trade union praxis and political culture. Top-down bargaining is a recipe for disaster and only an active and engaged membership will be able to lead from below. There are, of course, no simple and immediate solutions to democratizing and rebuilding workers' political capacities. Workers are not inherently radical or conservative but adapt to the structured conditions they encounter daily; thus politicization is always a process in motion. In this regard, attempting to democratize the union will require rebuilding relationships, educational and political capacities across not only the many layers and segments inside of the union, but also in the relationship of the union to the Left outside of organized labour, including the radical intelligentsia. This also speaks to the need to rebuild the small, fragmented and isolated Left outside of organized labour, thereby broadening the terrain of labour and social justice activism (Gindin, 2013).

Fifth, the turn in the "social-democratic" Miller regime toward neoliberalism already demonstrated that the old clientalistic relations between union leaders and progressive city councillors is long gone. Even 
individually supportive councillors could do little to prevent the decline of city services, selling-off of assets or the consolidation of neoliberalism across municipal sectors. Rather, a much more engaged and working class-centred strategy for Locals 79 and 416 is necessary if the focus is going to be on building active solidarity. For example, groups of union members could go on a door-to-door educational campaign to residents and local businesses in the community informing them of members' issues and in turn take stock of community concerns. While there will certainly be resistance from some residents and likely businesses, this could form part of an ongoing strategy for the union to develop the collective educational and political capacities of its members in addition to deeper ties with social justice and community groups. This could aid in not simply building connections within the groups that exist but also in developing the competencies and memberships of these groups as well to challenge the daily barrage of taken-for-granted neoliberal assumptions regarding public services, unions, taxation and so forth. All in all, creating a bolder public image means mobilizing members to make the connections between the services they provide and the communities they serve more visible.

Sixth, a greater emphasis needs to be placed on urbanizing Left strategy and tactics (Kipfer \& Saberi, 2014; Macdonald 2013). I offer one example which may be worthy of further discussion. Since community centres are located at the heart of various neighbourhoods, they serve as pivotal spaces for the exchange of information and discussion. Why not reclaim or occupy community centres as central spaces of the community via city providercommunity user alliances? The unwillingness to place such options on the agenda have had significant implications for other unionized workers (Rosenfeld, 2013). Unless Locals are prepared to force the issue onto the public agenda, such as occupying or reclaiming in the public interest a community centre would do, there can be little hope for the development of a mobilized and class-conscious movement fighting on behalf of their communities. The political potential of an "Occupy" community centre in coordination with community groups and activists, particularly in light of hundreds of millions in service cuts and tens of millions in new user-fees since the election of Rob Ford, is rife for all sorts of political openings..$^{13}$ But militant job actions are not enough. They need to be tied to different visions of the union and the city as a whole, ones that challenge the structural constraints of neoliberalism and the democratic shortcomings of liberal capitalism.

This might lead to communities demanding more decision-making power over the programs and events being held at their community centres, parks and public spaces, leafleting campaigns outside recreation and daycare centres, child and elder care facilities, public health and social assistance centres. These concerns could be communicated by pressuring local councillors, sitins, park protests, educationals and the creation of community caucuses made up of labour, social justice and other activists. Since the latter would be locally rooted, the potential exists for city-wide alliances and the development of a collective set of demands to begin thinking about and strategizing around. In 
short, job actions should be about most effectively demonstrating the many skills and competencies of city workers in ways that connect them with the communities they are rooted in, and the value in keeping them public. History has shown that this is not only possible but most successful. ${ }^{14}$

Finally, in addition to uniting with other unions' campaigns for public services, there may be ways of coordinating action with other community groups such as the Toronto Environmental Alliance, Workers Action Centre, Ontario Coalition Against Poverty, Social Planning Toronto and others in ways that reinforce existing campaigns or take on initiatives that the unions are not in a position to do. Rebuilding trade union capacities and working class politics in ways that mutually reinforce critical struggles in and around communities works on a number of intersecting levels. Because neoliberalism not only subjugates and attacks working people but integrates and builds upon workers' interdependencies, a successful project for union renewal must aim to rebuild not only the capacities of its members but those of the working class as a whole (Camfield, 2011; Fletcher \& Gapasin, 2008; Kumar \& Schenk, 2006; Turner \& Cornfield, 2007).

As part of this process, a renewed Left would need to have connections both inside and outside of the labour movement and seek to link these issues across workplaces, engage in political debates and organize across communities. This requires working to build the capacities of the entire union to fight back against concessionary demands, developing a movement inside the union that pushes for enhanced democratic participation and control, a radically feminist, antiracist, class struggle-oriented political praxis that engages with the struggles of the broader community, and educational efforts intent on building a cadre of workers and activists that embody both intellectual understanding and engagement.. ${ }^{15}$ As a final point, two recent experiences illustrate the importance of an anti-capitalist perspective both within trade unions and to the Left outside of organized labour. Under the leadership of the Caucus of Rank and File Educators (CORE), the Chicago Teachers Union (CTU) has recently moved in the direction of a radicalized labour approach which played a central role in combating the forces of privatization and corporate education reform (Brogan, 2014; Sustar, 2014). Likewise, although not a union struggle (although certainly union-influenced and generally supported), the Quebec student/popular movement of 2012 is suggestive. Led by the Coalition large de l'Association pour une solidarité syndicale (CLASSE), many engaged activists were anti-capitalists and the perspective that unified CLASSE - and was widely communicated throughout the movement-was largely anti-neoliberal with important segments of anti-capitalist activism and infused with a deep undercurrent of class politics (Ayotte-Thompson \& Freeman, 2012; Choudry \& Shragge, 2013; Solty, 2012). These two examples, while recent exceptions, illustrate the significance of a radicalized anti-capitalist approach for both labour and social justice activism in combating the austerity agenda and rekindling demands for social justice. 


\section{Conclusion and Directions for Future Research}

The City of Toronto has been in a steady state of decline in the quality of its public planning, services and infrastructure for several decades now. The foremost strategy of the Ford administration is to try and make do with even fewer public spaces and to leave as much room as possible for market forces to accommodate the continual pressures of urban growth. Notwithstanding Ford's own personal controversies, the conservative political agenda at City Hall continues largely unabated. Unions alone are incapable of posing alternative social and political strategies that reject corporatism. This requires a radicalized labour movement, left of social democracy, that can serve as a nodal point of community engagement and place a range of alternatives on the public agenda. Despite cascading series of defeats, however, this is not yet happening within the mainstream of organized labour. Like labour generally, the Left in Toronto continues to be divided into a panoply of coalitions without any coherence of strategy or programme. Changing this will require a radicalized labour and social justice movement that transcends activist sub-cultures, makes political demands and builds organizational capacities that are locally entrenched and territorially expanded. Without a strong municipal union strategy, deeply rooted in the community and forging new relationships with workers providing specific services and the users of those services, indications suggest Toronto city council will continue down this hard Right agenda with the avid support of ruling class circles.

Toronto civic workers face a historic test which may well set a precedent nationally, given the pivotal place of civic workers in public sector unions. Future research will need to assess to what extent urban labour struggles in Toronto mirror those in other cities and other regions. Given the pressures of urban austerity, how have other municipal unions fared in their negotiations with the city of Toronto? Are there certain segments (e.g. women, racialized workers) and services of the public sector disproportionately affected (e.g. librarians, recreation staff) or unaffected (e.g. police, fire)? If so, why or why not? How might union-community initiatives in other unions deepen and extend a revitalization of working class politics? What new political openings offer hope? Considering the multiplicity of pressures, time will tell if a major resistance is in the cards.

\section{Notes}

1 Carlo Fanelli is an Instructor and SSHRC Postdoctoral Research Fellow. Thanks are due to the editors and anonymous reviewers of Studies in Social Justice for their important suggestions, Greg Albo and Sam Gindin for comments on earlier drafts, as well as the Social Sciences and Humanities Research Council for funding this research. All errors are, of course, my own.

2 Recent scholarship regarding the growing spread of precarious work is also revealing new insights. Lewchuck et al. (2011) propose that the labour market may be in the midst of a major shift in the interrelationship between production and social reproduction. Their data suggests that men's and women's employment experiences are becoming 
increasingly similar. However, for the most part, this is not due to the improvement of women's employment opportunities and wages, but the result of the general downward convergence of wages and working conditions across the labour market. In other words, disparities typically associated with "feminized labour" are being replaced by dual precarious-earner households. As they argue, "White male workers can no longer assume that secure labour market positions are theirs, while new opportunities for hidden forms of both gender and racial privileging/discrimination have merged in the less secure segments of the labour market, in the pay differences, constant scheduling, and rehiring/firing of temporary and contingent work" (Lewchuk et al., 2011, p. 94).

3 Public sector unionism in Canada remains generally understudied. For an introduction to Canadian public sector unions see Ross and Savage, 2013 as well as Panitch and Swartz, 2003, and Swimmer and Thompson, 1995 for earlier explorations.

4 Section $92(8)$ of the Constitution Act grants the provinces complete authority over municipalities. Without the transfer of any administrative or fiscal supports like the ability to go into debt, print money and implement a range of tax measures (e.g. income, corporate, sales, resource and import taxes), municipalities rely predominantly on property taxes to raise revenue outside of federal and provincial transfers. And from this they must provide for their public utilities, public works, parks and recreational facilities, waste management, transit services, public housing and a whole range of other social and community services. Furthermore, because Ontario municipalities are prohibited from running a deficit, yearly budgets are regularly cost-crunching exercises as city councils seek to balance uncertain revenues with fluctuating demands for city services. As a consequence, the threat of fiscal bankruptcy distinguishes urban governance from national and provincial politics (Fanelli, 2014b).

5 Traditionally white- and pink-collar workers, Local 79 is the largest municipal local in Canada with a membership of 18,000 , although various contingent, seasonal and parttime workers push estimates of membership upwards to 24,000 . Local 416 is primarily made up of blue-collar workers and has approximately 6,200 members. Together, they work in areas of public health and education, child and elder care, parks, recreation, water treatment, Emergency Medical Services, as well as housing and court services, road maintenance, by-law and safety enforcement, building inspection, animal rescue, waste collection and social services administration. Some 79/416 members were deemed "essential" (e.g. EMS workers) and did not strike. Approximately 70 percent of Local 79's members are women, with some 50 percent representative of historically racialized groups. At least half are employed in part-time, seasonal and contingent forms of employment, with inconsistent hours and without the supplemental health benefits enjoyed by full-time employees.

6 Parts of this section are drawn from Fanelli, 2014a where they are explored in greater detail.

7 In fact, the election of Rob Ford owes a great deal to the debacle of 2009 as he explicitly campaigned on reigning-in allegedly overgenerous wages and benefits, and reducing the "gravy train" at City Hall. Rob Ford has been very clear that "the gravy is in the number of employees we have at City Hall." No evidence of irresponsible spending, inefficient service delivery and unproductive workers has been found, yet city employees and the users of its services are now being characterized as dependents of the state. Toronto's public service has already been reduced by more than 2,300 workers, mostly through attrition and leaving vacancies unfilled since Ford took office. In 2012, the City announced 1,200 layoffs, with plans to further reduce the City's 50,000 person workforce by another 5,000 positions by the October 2014 election (Dale, 2011).

8 Toronto Public Library workers' contracts expired around the same time as Locals 79 and 416. Half of the 1,500 CUPE Local 4948 members are employed part-time and three-quarters are women. The City was essentially trying to rollover the parameters of the 79/416 contract, which would build on the prior elimination of 100 positions and sought to cut 10 percent from the Library's operating budget. Local 4948 positions have been reduced by 17 percent since amalgamation, even though Toronto Public Library usage grew 29 percent. Part-time members have difficulty securing full-time work, and rarely qualify for benefits; even though they must pay 40 percent of those benefits, only 22 percent qualify. A major sticking point throughout negotiations was the City's 
trying to remove a clause that made seniority a factor in assigning part-time shifts, as well as a clause that prohibited layoffs in the event of technological displacement or the elimination of positions. Having reached an impasse, on March 18, 2012, Local 4948 struck. The union received much more widespread public support and media sympathy than did Locals 79/416. Eleven days later the strike was ended with a new agreement. Under the terms of the new four-year deal, full-time and part-time workers are protected from layoffs after eleven years (unlike 79/416s 15 years) seniority. Local 4948 members also received a lump sum payment of 1.5 percent in 2012, 0.225 in 2013, 1.75 in 2014 and 2.25 in 2015 as well as the creation of some new full-time positions. It is important to note that back loading wage increases to the final year of the contract is an insidious strategy on the part of employers used to manufacture a financial crisis using the uptick in wages as a rationale. There have yet to be any scholarly post-strike assessments.

9 A lack of coordination among CUPE Locals was compounded because Local 79 was in the process of electing a new president and executive. Local 79, or the other two CUPE Locals bargaining 4948 and 2998 for example, could have served notice to begin bargaining earlier but they did not, which may have been a significant strategic mistake.

10 In Canada, this tactic was brought to light in Ontario when college administrators threatened to unilaterally impose the terms of the agreement unless unionized instructors accepted concessions in 2009-10. After forcing a contract on instructors, just 51 percent of the union accepted the agreement (CBC, 2010). In a similar fashion, unless CUPE Locals accepted the terms of the agreement, the City made clear it would simply implement their final offer. The union could then either strike completely, implement rotating strikes, work-to-rule, or choose to continue bargaining with the City.

11 Indicative of the authoritarian neoliberalism at City Hall and so-called tough-on-crime approach, in 2011 Toronto police were awarded an 11.5 percent wage increase (about $\$ 100$ million) over four years. With this in mind, Locals 79 and 416 and other unionized workers in the City of Toronto need to make clear the class function and repressive nature of police work and begin a discussion about why not all City workers are treated equally, as the outcome of these negotiations seem to suggest.

12 Consider child care and recreation. Ford has been very clear in suggesting that Toronto's 24,000 child care spaces should be privatized. Council recently moved to eliminate 2,000 subsidized spaces that were previously cost-shared with the province. As such, affordable child care remains one of the most sorely needed services in the city (and the country) with nearly 20,000 children still wait-listed. What's more, in 2011 the Chair of the Community Development and Recreation Committee, Giorgio Mammoliti, argued that the city should get out of the business of directly providing childcare and recreational services, suggesting that elimination of programs or contracting-out was preferable. With over 650 city-subsidized child care centres in the city, Local 79 could have made this a real public services and media issue and engaged directly in a campaign with parents and caregivers to "keep the service public" while drawing attention to the crisis in affordable child and afterschool care more generally.

13 Additionally, for example, Local 79 might look to take a more interventionalist approach in the communities its members serve. Since Animal Services is an important part of the city, what if union headquarters or community centres, parks, public spaces, etc., held 'animal information events' and gave community members an opportunity to bring their animals out so that they could ask questions, creating relationships between workers and community members, and publicizing the other services workers supply. Or perhaps offered health and fitness assessments provided by healthcare professionals, questions for child and elder care workers, discussions with city architects, planners and transit specialists, etc. These are just a few small-scale examples that might offer a more effective use of workers' diverse skill sets, which could form part of a broader public relations and engagement strategy.

14 Recently, striking museum workers in Ottawa and Gatineau put together regular cultural events that normally would have taken place inside the museum, but held them outside instead. These events were open to the public and provided the workers with an opportunity to organize and work together on the picket line in a fulfilling way. The successful execution of the events, such as the one honouring veterans on Remembrance Day and the "picket line tea party" held in celebration of Prince Charles' visit to Canada 
contributed in a substantial way to workers' ability to maintain their spirits throughout the strike. The events also demonstrated the skill and creativity of workers to the public, as well as presented them as a valuable and productive force. This was especially clear when the Museum of Civilization opened the "Afghanistan: Hidden Treasures" exhibit and the workers created their own featuring themselves and entitled "Striking Treasures." As striking workers gained confidence through concerted action, and the support of the community mounted, there was a clear turn toward a more class conscious unionism as the connections between the employed and unemployed, communities and workplaces, became all the more clear. See Fanelli and Lefebvre, 2011. See also the experiences of cleaners in the city of Toronto, Carson and Siemiatycki, 2014.

15 Efforts to democratize Local 79 have resurfaced at many different points over the last decade. The most recent was in response to the failure of 2009. A core of activist members with a commitment to social justice began the Local 79 Reform Caucus. After a few months of organizing, however, the caucus stagnated then disappeared owing to worker burnout due to a disproportionate share of organizing borne by a small group of members. The reasons for how and why such reform movements fail or succeed and the challenges they encounter are important areas of future research.

\section{References}

Albo, G. (2009). Challenges for urban social justice movements, neoliberal urbanism, the Canadian city and Toronto. Toronto: Centre for Social Justice.

Albo, G., \& Fanelli, C. (2014, forthcoming). Austerity Against Democracy: An Authoritarian Phase of Neoliberalism? Teoria Politica: An International Journal of Theory and Politics

Armstrong, P., Amaratunga, C., Bernier, J., Grant, K., Pederson, A., \& K. Willson, (Eds.). (2001). Exposing privatization: Women and health care reform in Canada. Aurora, Ontario: Garamond Press.

Ayotte-Thompson, M. \& L. Freeman. (2012). Accessibility and privatization: The Quebec student movement. Social Policy, Fall 2012, 1-6.

Baines, D. (2013). Unions in the non-profit social services sector: Gendered resistance. In S. Ross \& L. Savage, (Eds.), Public sector unions in the age of austerity (pp.80-102). Halifax: Fernwood Publishing.

Baines, D. (2004). Caring for nothing: Work organization and unwaged labour in social services. Work, Employment and Society, 18(2), 267-295.

Block, S., \&. Galabuzi, G. E. (2011). Canada's colour coded labour market: The gap for racialized workers. Ottawa: Canadian Centre for Policy Alternatives.

Boudreau, J. A. (2000). The megacity saga. Nova Scotia: Black Rose Books.

Boudreau, J. A., Keil, R., \& Young, D. (2009). Changing Toronto: Governing urban neoliberalism. Toronto: University of Toronto Press.

Braedley S., \& Luxton M. (Eds). (2010). Neoliberalism and everyday life. Montreal \& Kingston: McGill-Queen's University Press.

Brenner, N., \& Theodore, N. (Eds.). (2002a). Spaces of neoliberalism: Urban restructuring in North America and Western Europe. Oxford: Blackwell.

Brenner, N., \& Theodore, N. (Eds.). (2002b). Cities and the geographies of "actually existing neoliberalism." Antipode, 34(3), 349-379

Brenner, N., \& Theodore, N. (Eds.). (2005). Neoliberalism and the Urban Condition. CITY, 9(1), 101-107.

Briskin, L. (2013). In the public interest: Nurses on strike. In S. Ross \& L. Savage, (Eds.), Public sector unions in the age of austerity (pp. 91-102). Halifax: Fernwood Publishing.

Brogan, P. (2014). Getting to the CORE of the Chicago Teachers' Union transformation. Studies in Social Justice

Camfield, D. (2011). Canadian labour in crisis: Reinventing the workers' movement. Halifax: Fernwood Publishing.

Carson, J., \& Siemiatycki, M. (2014, forthcoming). The justice and dignity for cleaners' campaign: mobilizing against precarity in Toronto. Just Labour: A Canadian Journal of Work and Society 
Caulfield, J. (1994). City form and everyday life: Toronto's gentrification and critical social practice. Toronto: University of Toronto Press.

CBC (2010, February 24). Ontario College Teachers Accept Deal, Avert Strike. http://www.cbc. ca/news/canada/ottawa/ontario-college-teachers-accept-deal-avert-strike-1.964255

Choudry, A. \& E. Shragge. (2013). The 2012 student strike: Many lessons were learned and taught. Social Policy, Spring 2013, 11-14

Dale, D. (2011, September 15). Ford Says City Employees Are the Gravy. Toronto Star, http:// www.thestar.com/news/gta/2011/09/15/ford_says_city_employees_are_the_gravy.html

Dale, D. \& T. Boyle. (2012, February 13). City Workers to Get 6\% Over Four Years. Toronto Star, http://www.thestar.com/news/city_hall/2012/02/13/city_workers_to_get_6_pay_hike_ over_four_years.html

Evans, B. (2013). When Your Boss is the State: The Paradoxes of Public Sector Work. In S. Ross \& L. Savage, (Eds.), Public sector unions in the age of austerity (pp.18-30). Halifax: Fernwood Publishing.

Fanelli, C. (2013). Fragile future: The attack against public services and public sector unions in an era of austerity. Unpublished doctoral dissertation. Carleton University, Ottawa.

Fanelli, C. (2014a). Neoliberal urbanism and the assault against public services and workers in Toronto, 2006-2011. Articulo: Journal of Urban Research http://articulo.revues.org/2380

Fanelli, C. (2014b, forthcoming). Municipal neoliberalism and Ontario. In G. Albo, \& R. MacDermid, (Eds.), Divided province: Ontario politics in the age of neoliberalism. Toronto: University of Toronto Press.

Fanelli, C. (2014c, forthcoming). Reviving working class politics: Canadian labour and the struggle for public services. New Proposals: Journal of Marxism and Interdisciplinary Inquiry.

Fanelli, C., \& Paulson, J. (2012). Municipal malaise: Neo-liberal urbanism in Canada. In L. Tepperman \& A. Kalyta, (Eds.), Reading sociology: Canadian perspectives (223-226). Toronto: Oxford University Press.

Fanelli, C., \& Lefebvre, P. (2011). The Ottawa and Gatineau Museum Workers' strike: precarious employment and the public sector squeeze. In Fanelli, C. \& P. Lefebvre, (Eds.), Critical Social Research in Critical Times, Alternate Routes 2012 (pp. 121-145). Ottawa: Red Quill Books.

Friskin, F. (1993). Planning and servicing the Greater Toronto Area: The interplay of provincial and municipal interests. In D. Rothblatt \& A. Sancton (Eds.), Metropolitan governance: American/Canadian intergovernmental perspectives (pp. 153-204). Berkeley: University of California.

Fletcher, B., Jr., \& Gapasin, F. (2008). Solidarity divided: The crisis in organized labor and a new path toward social justice. Berkeley: University of California Press.

Fudge, J. \& Tucker, E. (2001). Labour before the law: The regulation of workers' collective action in Canada, 1900-1948. Toronto: Oxford University Press.

Gindin, S. (2013). Beyond the economic crisis: The crisis in trade unionism. In C. Fanelli \& B. Evans, (Eds.)., Great recession-proof? Shattering the myth of Canadian exceptionalism, Alternate Routes 2013 (pp. 236-245). Ottawa: Red Quill Books.

Grant, K. (2012, April 16). Ford team set tone for municipal labour talks. Globe and Mail, http:// www.theglobeandmail.com/news/toronto/ford-team-set-tone-for-municipal-labour-talks/ article4170538/

Hackworth, J. (2007). The neoliberal city: Governance, ideology and development in American urbanism. Ithaca: Cornell University Press.

Harvey, D. (1996). Justice, nature and the geography of difference. Oxford: Blackwell.

Harvey, D. (2009). Social justice and the city. Georgia: University of Georgia Press.

Harvey, D. (2013). Rebel cities: From the right to the city to the urban revolution. London: Verso

Jenson, J., \& M. Sineau. (2001). Who cares? Women's work, child care, and welfare state redesign. Toronto: University of Toronto Press

Keil, R. (2002). "Common-Sense" Neoliberalism: Progressive conservatism in Toronto, Canada. Antipode, 34(3), 578-601.

Keil, R. (1998). Toronto in the 1990s. Dissociated governance? Studies in Political Economy, $56,151-167$

Kipfer, S., \& Keil, R. (2002). Toronto Inc? Planning the competitive city in the new Toronto. Antipode, 34(2), 227-264. 
Kipfer, S., \& Saberi, P. (2014, forthcoming). From "revolution" to farce? Hard-right populism in the making of Toronto. Studies in Political Economy

Kumar, P., \& Schenk, C. (Eds.). (2006). Paths to union renewal: Canadian experiences. Peterborough, ON: Broadview Press.

Lemon, J. (1985). Toronto since 1918. Toronto: James Lorimer Press.

Lewchuk, W., Clarke, M., \& De Wolff, A. (2011). Working without commitments: The health effects of precarious employment. Montreal \& Kingston: McGill-Queen Press.

Loxley, J. (2010). Public service private profits: The political economy of public-private partnerships in Canada. Halifax, Nova Scotia: Fernwood Publishing.

Mann, M. (1973). Consciousness and action among the western working class. London: Macmillan.

McBride, S. (2001). Paradigm shift: Globalization and the Canadian state. Halifax: Fernwood.

Macdonald, I. (2013) Beyond the labour of Sisyphus: Unions and the city. In Panitch, L., G. Albo \& V. Chibber, (Eds.), Registering Class, Socialist Register 2014 (pp. 247-265). London: Merlin.

McDonough, P., Worts, D., Fox, B., \& Dmitrienk, K. (2008). Restructuring municipal government: Labour-management relations and workers mental health. Canadian Review of Sociology, 45(2), 197-219

Moody, K. (1997). Workers in a lean world: Unions in the international economy. London: Verso Press.

Panitch, L., \& Swartz, D. (2003). From consent to coercion: The assault on trade union freedoms. Aurora, ON: Garamond Press.

Peck, J. (2010). Constructions of neoliberal reason. Oxford: Oxford University Press.

Peck, J. (2012). Austerity urbanism: American cities under extreme economy. CITY, 16(6), 626655.

Peck, J. (2013). Pushing austerity: State failure, municipal bankruptcy, and the crises of fiscal federalism in the USA. Cambridge Journal of Regions, Economy and Society, 7(1), 17-44

Peck, J., \& Tickell, A. (2002). Neoliberalizing space. Antipode, 34(3), 380-404

Personal Communication 1. (2013, November 26). Interview with Local 79 Trade Unionist A.

Personal Communication 2. (2013, December 8). Interview with Local 79 Trade Unionist B.

Pupo, N., \& Noack, A. (2010). Dialing for service: Transforming the public-sector workplace in Canada. In N. Pupo \& M. Thomas, (Eds.), Interrogating the new economy: Restructuring work in the 21st Century (pp. 111-128). Toronto: University of Toronto Press

Ridler, D. (2012, February 5). Strike averted: City and outside workers reach tentative agreement. Toronto Star, http://www.thestar.com/news/gta/2012/02/05/strike_averted_city_ and_outside_workers_reach_tentative_agreement.html

Ross, S. (2005). The making of CUPE: Structure, democracy and class formation. Unpublished doctoral dissertation. York University, Toronto.

Ross, S., \& Savage, L. (Eds.) (2013). Public sector unions in the age of austerity. Halifax: Fernwood Publishing.

Rosenfeld, H. (2013). The electro-motive lockout and non-occupation: What did we lose? What can we learn? In Fanelli, C. and B. Evans, (Eds.), Great recession-proof? Shattering the myth of Canadian exceptionalism, Alternate Routes 2013 (pp. 220-235). Ottawa: Red Quill Books.

Sears, A. (1999). The "lean" state and capitalist restructuring: Towards a theoretical account. Studies in Political Economy, 59, 91-114

Solty, I. (2012). Canada's "Maple Spring": from the Quebec student strike to the movement against neoliberalism. The Bullet, no.752, http://www.socialistproject.ca/bullet/752.php

Stanford, J. (2013, September 4). Unifor: Canada's newest union. Rabble, http://rabble.ca/ columnists/2013/09/unifor-canadas-newest-union

Stedman Jones, D. (2013). Masters of the universe: Hayek, Friedman and the birth of neoliberal politics. Princeton, New Jersey: Princeton University Press.

Stinson, J. (2010). Labour casualization in the public sector. In N. Pupo, \& M. Thomas, (Eds.), Interrogating the new economy: Restructuring work in the 21st century (pp. 93-110). Toronto: University of Toronto Press.

Sustar, L. (2014). Striking back in Chicago: How teachers took on city hall and pushed back education "reform." Chicago: Haymarket Books.

Swimmer, G., \& Thompson, M. (Eds.). (1995). Public sector collective bargaining in Canada: 
The beginning of the end or the end of the beginning? Kingston, ON: IRC Press.

Todd, G. (1998). Megacity: Globalization and governance in Toronto. Studies in Political Economy, 56, 193-216.

Toronto Environmental Alliance. (2011). Look before you leap: An environmental perspective on privatizing waste collection in Toronto. Toronto: TEA.

Turner, L., \& Cornfield, D. (Eds.). (2007). Labor in the new urban battlegrounds: Local solidarity in a global economy. Ithaca: Corneall University Press/ILR Press.

Vosko L. F., (Ed.). (2006). Precarious employment: Understanding labour market insecurity in Canada. Montreal \& Kingston, McGill-Queen's University Press.

Warskett, R. (2013). Federal public sector unions in times of austerity: Linking structure and strategic choice. In S. Ross \& L. Savage, (Eds.), Public sector unions in the age of austerity (pp. 126-138). Halifax: Fernwood Publishing.

Williams, R. (1989). Resources of Hope. London: Verso Press.

Worts, D., Fox, B., \& McDonough, P. (2007). "Doing something meaningful": Gender and public service during municipal government restructuring. Gender, Work and Organization, 14(2), 162-184 